\title{
Author university affiliation
}

\author{
Apio Antunes ${ }^{1}$ (1) \\ ${ }^{1}$ Neurosurgical Unit, University Hospital, Porto Alegre Medical \\ School, Porto Alegre, Rio Grande do Sul, Brazil \\ Arq Bras Neurocir 2021;40(3):e294.
}

Dr. Eberval Figueiredo Editor-in-Chief

Brazilian Journal of Neurosurgery

Dear Dr. Eberval:

In the recent volume 39(2) of the Brazilian Journal of Neurosurgery, we were deeply and negatively surprised with the finding in the article "Microsurgical and Endoscopic Anatomy of the Cavernous Sinus", coaoutohored by yourself. The first author aludded to be a member of our University (Universidade Federal do Rio Grande do Sul). Unless this was done by an improper digitation error, we, here, never found any position of this doctor in our Medical School. This being so, according to the possible legal and ethical responsibilities,
Address for correspondence Apio Antunes, MD, MSc, PhD, IFAANS, Neurosurgical Unit, Porto Alegre Medical School, University Hospital, Porto Alegre, Rio Grande do Sul, Brazil (e-mail: aantunes@hcpa.edu.br).

we ask prompt manifestation of the authors or the journal for proper corrections and explanations.

Porto Alegre February 23, 2021

Apio Antunes

Apio Antunes, MD, MSc, PhD,IFAANS

Chairman of Neurosurgical Unit, University Hospital

Associate Professor of Neurosurgery

Porto Alegre Medical School

\section{Conflict of Interest}

The author has no conflicts to declare. received

July 21, 2021

accepted

July 28, 2021
DOI https://doi.org/

10.1055/s-0041-1735151.

ISSN $0103-5355$.

\footnotetext{
(c) 2021. Sociedade Brasileira de Neurocirurgia. All rights reserved. This is an open access article published by Thieme under the terms of the Creative Commons Attribution-NonDerivative-NonCommercial-License, permitting copying and reproduction so long as the original work is given appropriate credit. Contents may not be used for commercial purposes, or adapted, remixed, transformed or built upon. (https://creativecommons.org/ licenses/by-nc-nd/4.0/)

Thieme Revinter Publicações Ltda., Rua do Matoso 170, Rio de Janeiro, RJ, CEP 20270-135, Brazil
} 